\title{
Total nonstructural carbohydrate trends in Chinese tallow roots
}

\author{
WARREN C. CONWAY, LOREN M. SMITH, RONALD E. SOSEBEE, AND JAMES F. BERGAN
}

Authors are research assistant, Kleberg Professor of Wildlife Ecology, and professor, Department of Range, Wildlife, and Fisheries Management, Texas Tech University, Lubbock, Tex. 79409-2125, and Coastal Land Steward, The Nature Conservancy of Texas, Corpus Christi, Tex., 78403-2563.

\begin{abstract}
Chinese tallow (Sapium sebiferum L. Roxb.) was introduced to the United States from China in the mid to late 1800s and has since naturalized throughout much of the southern $U$. S. Tallow continues to invade a wide variety of habitats, but control efforts have been inconsistent. We related root total nonstructural carbohydrate (TNC) levels and phenological development in Chinese tallow over an annual cycle to determine optimal timing for control treatments. Six phenological stages were recorded; (1) dormancy, (2) bud break, (3) leaf development, (4) seed formation, (5) seed maturation, and (6) leaf fall. Tallow root TNC concentrations varied by phenological stage $(P<0.001)$, where concentrations were highest $(P$ $<0.05)$ during leaf fall $(60.72 \%)$ and lowest during leaf development $(41.11 \%)$ and seed formation $(36.71 \%)$. Chinese tallow root TNC concentrations increased during the period of seed maturation until leaf fall. If foliar applied herbicides are delivered during this period of downward translocation, effective tallow control may be observed.
\end{abstract}

Key Words: exotic plant control; restoration; Sapium sebiferum; total nonstructural carbohydrate trends

Chinese tallow (Sapium sebiferum L. Roxb), is a deciduous woody tree that was introduced into the United States in the mid to late 1800s (Scheld et al. 1984, Bruce 1993, Bruce et al. 1997). Tallow has since invaded much of the southern U. S. along the Atlantic and Gulf Coasts in floodplain forests, freshwater wetland basins, coastal prairie, abandoned rice fields, mixed bottomland hardwood forests, as well as disturbed sites (Hunt 1947, Russell et al. 1969, Cameron and LaPoint 1978, Scheld and Cowles 1981, Scheld et al. 1984, Jones and McLeod 1990, Bruce 1993, Jones 1993, Jubinsky 1994, Bruce et al. 1997). Due to the severity of the invasion (Jones and McLeod 1989, 1990; Bruce 1993, Conner 1994, Jubinsky 1994, Bruce et al. 1997) tallow control (both chemical and mechanical) has begun to receive interest, although results have been inconsistent (Jubinksy 1994). The efficacy of dif-

Research was funded in part by the U S. Fish and Wildlife Service, The Nature Conservancy of Texas, Monsanto Chemical Company, and Texas Tech University. This is manuscript T-9-000 of the College of Agricultural Sciences, Texas Tech University.

Manuscript accepted 20 October 1997

\section{Resumen}

"Chinese tallow" (Sapium sebiferum L. Roxb.) fue introducido a Estados Unidos en la segunda mitad del siglo pasado y desde entonces se ha naturalizado en gran parte del sudeste de Estados Unidos. "Tallow" aun continua invadiendo una amplia variedad de hábitats, y los esfuerzos de control han sido inconsistentes. Relacionamos los niveles de carbohidratos noestructurales totales de la raíz (CNT) y el desarrollo fenológico del "Chinese tallow" a través del año para determinar la época óptima de aplicación de tratamientos de control. Se registraron 6 etapas fenológicas: (1) dormancia, (2) brotación de yemas, (3) desarrollo de hojas, (4) formación de semilla, (5) maduración de semilla y (6) caída de hojas. La concentración de CNT de la raíz del "Tallow" varió con la etapa fenológica $(\mathbf{P}<\mathbf{0 . 0 0 1})$, la mayor concentración de carbohidratos $(P<0.05)$ ocurrio en la etapa de caída de hojas $(60.72 \%)$ y la menor durante el desarrollo de hojas $(\mathbf{4 1 . 1 1 \%})$ y formación de semilla $(36.71 \%)$. La concentración de CNT de la raíz del "Chinese tallow" se incrementó durante el período de maduración de la semilla hasta la caída de hojas. Si se aplican herbicidas foliares durante el período de translocación de carbohidratos hacia la raíz se puede observar un control efectivo del "Tallow".

ferent control techniques on Chinese tallow has been reviewed (Jubinsky 1994, Bruce et al. 1997). Mechanical removal of mature trees may be impractical on a region-wide scale due to (1) extensive woodland sizes, (2) expense in such operations, and (3) tallow's ability to vigorously resprout after physical damage (Scheld and Cowles 1981, Jubinsky 1994, Bruce et al. 1997). Biological control has received some interest, but the expense and difficulty in finding a species specific pathogen on tallow has hindered such efforts (Jubinsky 1994). Foliarand stump-applied herbicidal treatments have been partially successful, but to date, region-wide herbicidal treatment programs have not been implemented (Jubinsky 1994, Bruce et al. 1997).

Root total nonstructural carbohydrate (TNC) reserve cycling is a fundamental ecophysiological plant process (Glerum 1980, Hopkins 1995). Root TNC levels are often correlated with phenological development and used to make management recommendations for herbicidal control treatments (Coyne and Cook 1970, Wilson et al. 1975, Menke and Trlica 1981, Fick and Sosebee 1983, Sosebee 1983). Using root 
TNC patterns for woody plant control differs from past control practices which emphasized either (1) identifying a specific herbicide that would kill any plant or (2) identifying specific calendar dates for herbicidal treatments (Sosebee 1983). Neither approach has been consistently successful for woody plant control on a region-wide scale (Sosebee 1983). By timing foliar herbicidal application with downward TNC translocation, herbicides will be assimilated into the perennating buds and organs, where total plant kill should be observed (Boo and Pettit 1975, Wilson et al. 1975, Brady and Hall 1976, Fick and Sosebee 1983, Sosebee 1983). The objectives of this study were to test the hypothesis that Chinese tallow root TNC levels vary during the annual cycle according to demands of different stages of phenological development and develop Chinese tallow control timing recommendations based on TNC movement and phenological development.

\section{Study Area}

This study was conducted along the mid-Texas Coast at The Nature Conservancy of Texas' Mad Island Marsh Preserve (MIMP) $\left(28^{\circ} 6^{\prime} \mathrm{N} 95^{\circ}\right.$ $\left.8^{\prime} \mathrm{W}\right)$ in Matagorda County and at the Brazoria National Wildlife Refuge (BNWR) (29 10' $\left.\mathrm{N} 95^{\circ} 8^{\prime} \mathrm{W}\right)$ in Brazoria County (Fig. 1). In 1995, a riparian and wetland basin woodland were selected from the MIMP and BNWR, respectively. Both woodlands were dominated by Chinese tallow trees, characterized by high amounts of plant litter on the woodland floor, with ground cover ranging from 45.1 to $64.2 \%$ and canopy heights ranging from 9.75 to $11.33 \mathrm{~m}$ (Conway 1997). Various sedges (Carex spp.) and rushes (Juncus spp.) comprised 14.7 to $24.8 \%$ and 6.0 to $11.1 \%$ of the understory in woodlands at BNWR, respectively, but were infrequently encountered in MIMP. Dewberry (Rubus trivialis) was encountered in all woodlands comprising 1.9 to $10.9 \%$ of the understory at MIMP but $\leq 2.5 \%$ at BNWR. Chinese tallow seedlings comprised $<10 \%$ of the understory, but the woodlands had similar amounts of young tallow trees (i.e., number stems $>1 \mathrm{~cm}$ diameter at breast height $[\mathrm{dbh}] / \mathrm{m}^{2}$ ), ranging from 0.32 to

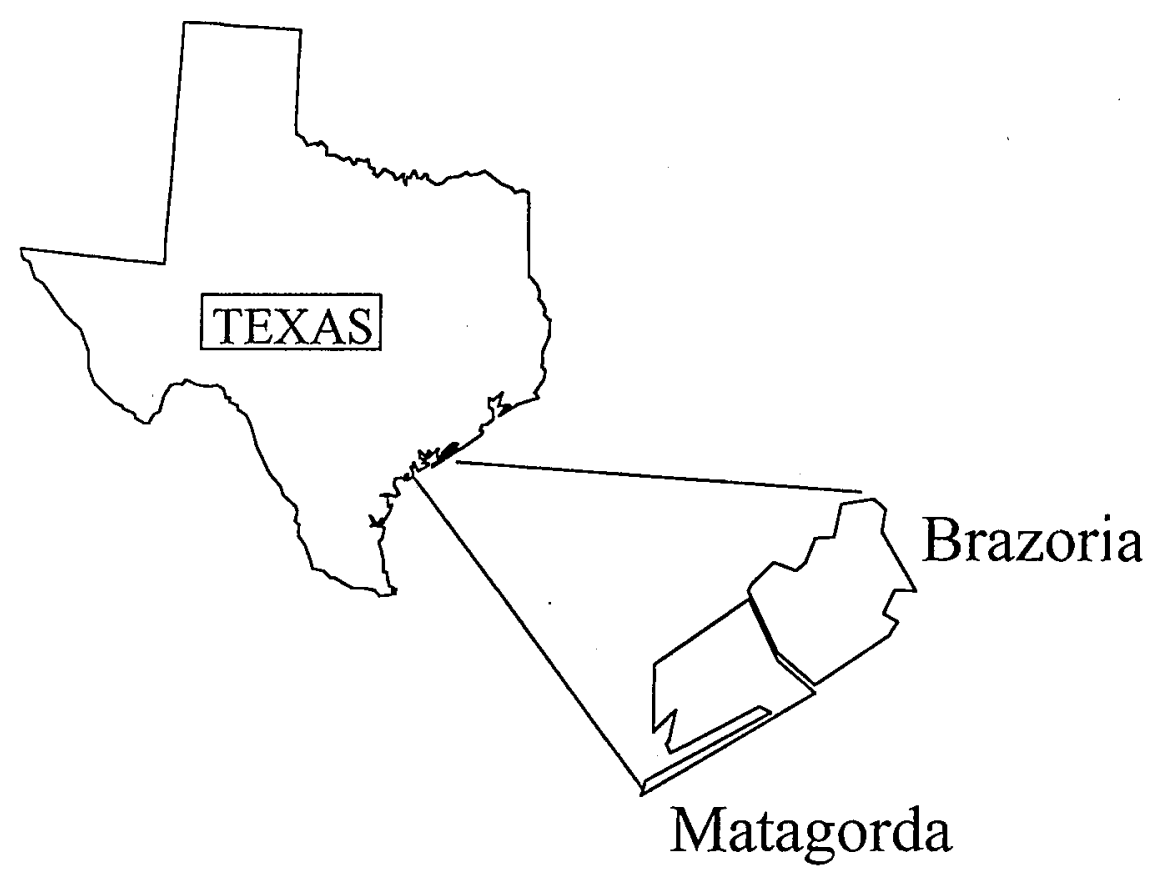

Fig. 1. Location of Chinese tallow study areas along the Texas Coast during 1995 and 1996.

0.42 stems $/ \mathrm{m}^{2}$. The woodland at MIMP had more large trees (i.e., number of tal-

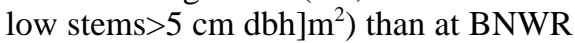
(Conway 1997).

The mid-Texas coast is coastal prairie, encompassing a region of over $38,000 \mathrm{~km}^{2}$ It is restricted to a $40-60$ $\mathrm{km}$ wide band along the coast of the Gulf of Mexico from the Louisiana border to the semi-arid regions of south Texas near Kingsville (Smeins et al. 1992). Diamond and Smeins (1984) described the region as having a mean annual temperature of $20-22^{\circ} \mathrm{C}$ with a frost free period of 240-320 days. The region is flat, ranging in elevation from 20-75 m (Smeins et al. 1992) with poor drainage. The geology consisted of Beaumont and Montgomery formations, composed of thick beds of sand interspersed with layers of clay and silt (Smeins et al. 1992). Soils of the region consist of dense clay subsoils and are waterlogged during winter, but may exhibit droughty characteristics during dry conditions (Smeins et al. 1992).

\section{Materials and Methods}

\section{Root Collection}

Chinese tallow roots were collected monthly from November 1995 through October 1996 from the riparian woodland at Mad Island Marsh Preserve (MIMP) and the wetland basin wood- land at Brazonia National Wildlife Refuge (BNWR.) These 2 habitats were selected to examine possible differences in tallow root TNC trends among different woodland types. Roots were excavated from the main tap root, below the basal bud zone of 4 randomly selected tallow trees in each woodland during each month (Wilson et al. 1975). Phenological stage of development was recorded for each sample tree. Each tree was inspected for signs of phenological change over the annual cycle. The following phenological stages were recorded as observed: (1) dormancy, (2) bud break, (3) leaf development, (4) seed formation, (5) seed maturation, and (6) leaf fall.

Tallow trees generally have a main tap root with associated lateral roots. Therefore, during root collection, extraneous lateral roots were removed to access the main tap root for sample collection. If the tree was small enough, the entire tap root was removed. If a tree could not be pushed over, a hole was excavated and a section of the main tap root was removed using a pick-axe and shears. Once removed, roots were put into paper bags, and placed on dry ice to prevent enzymatic degradation of TNCs (Boo and Pettit 1975, Wilson et al. 1975). Roots were then placed into a drying oven at $100^{\circ} \mathrm{C}$ for 1 to 2 hours to halt enzymatic activity (Boo and Pettit 1975, Mounsif 1986). They were then 
dried at $60-65^{\circ} \mathrm{C}$ for 1 week to remove any moisture (Boo and Pettit 1975, Sosebee pers. commun.). After drying, roots were ground into a powder using a Wiley mill fitted with a 40 mesh $(0.5$ mm) screen (Menke and Trlica 1981, Mounsif 1986). Only clean, unblemished root sapwood was used for grinding to prevent contaminating samples with dirt, bark, or other foreign substances (Sosebee, pers. commun.). All root samples were kept in air-tight glass containers until analyzed for TNC.

\section{Root TNC Chemical Analysis}

Ground tallow roots were subjected to the anthrone reagent procedure (Yemm and Willis 1956, Mounsif 1986) to determine root TNC concentration (Wan and Sosebee 1990). Individual root samples were divided into 3 subsamples $(0.5$ g). Each subsample was digested by boiling $60 \mathrm{ml}$ of hydrochloric acid $(\mathrm{HCl})$ in $300 \mathrm{ml}$ flasks for 2 hours (Boo and Pettit 1975, Mounsif 1986). After digestion, samples were cooled and filtered into $100 \mathrm{ml}$ volumetric flasks using Whatman No. 2 filter paper. Once filtered, each flask was brought to volume using distilled water. A $1 \mathrm{ml}$ aliquot was then removed and placed into a $35 \mathrm{ml}$ test tube containing $4 \mathrm{ml}$ of distilled water. The test tube mixture was shaken using a Thermolyne vortex mixer (30 $\mathrm{sec})$. A $1 \mathrm{ml}$ aliquot was then removed from the original test tube and placed into another $35 \mathrm{ml}$ test tube containing $10 \mathrm{ml}$ of anthrone reagent. Test tubes were shaken using the Thermolyne 8 vortex mixer $(30 \mathrm{sec})$. Sample test tubes were then placed into a heater block for $17 \mathrm{~mm}$ at $96-100^{\circ} \mathrm{C}$, after which they were removed and placed into a cold $\left(22^{\circ} \mathrm{C}\right)$ water bath until they reached room temperature. Once at room temperature, samples were analyzed with a
Perkin-Elmer Lambda 3B UV/VIS spectrophotometer set at $612 \mathrm{~nm}$, using glucose as the standard. Root TNC concentrations were calculated by dividing the sample spectrophotometric readings by the glucose standard to obtain a percent (\%) TNC value on a dry $\mathrm{mg} / \mathrm{g}$ basis.

\section{Data Analysis}

A 2-way analysis of variance (ANO VA) was used to test for overall differences in root TNC concentration (\%) between woodland types (i.e., riparian or wetland basin) and among phenological stages (i.e., dormancy, bud break, leaf development, seed formation, seed maturation, and leaf fall). Although roots were collected on a monthly basis, phenological stage of development was the independent variable during analyses to focus on phenological, not monthly variation in root TNC concentrations. Percentage tallow root TNC concentration data were square root transformed (Zar 1996). If differences $(\mathrm{P}<0.05)$ occurred, least squares mean separation was used to examine differences among phenological stages in root TNC concentrations. However, the means were back-transformed for presentation.

\section{Results}

There was no woodland type by phenological stage $(\mathrm{F}=1.30 ; 5,180 \mathrm{df} ; \mathrm{P}=$ $0.266)$ interaction. There was no woodland type $(\mathrm{F}=1.15 ; 1,180 \mathrm{df} ; \mathrm{P}=$ 0.286) effect (Table 1). Root TNC concentrations varied by phenological stage $(\mathrm{F}=18.65 ; 5,180 \mathrm{df} ; \mathrm{P}<0.001)$. Tallow root TNC concentrations were highest during leaf fall and lowest during leaf and seed development $(\mathrm{P}<0.05)$.

\section{Discussion}

Chinese tallow root TNC trends follow patterns similar to other woody species such as mesquite (Prosopis glandulosa), sand-shin oak (Quercus havardii), cherry (Prunus avium), and poplar clones (Populus tristis x balsamifera) (Boo and Pettit 1975, Wilson et al. 1975, (Glerum 1980, Isebrands and Nelson 1983, Loescher et al. 1990, Wan and Sosebee 1990). Tallow root TNC levels rapidly decrease during spring when trees break dormancy, buds break, roots grow, and leaves develop. During these periods, roots function as carbohydrate sources, supplying energy to meet increased metabolic costs (sensu Hopkins 1995). Tallow root TNC levels continue to decline through the seed formation phase. Once tallow seeds begin to ripen and mature, root TNC levels increase. These fluctuations in root source/sink dynamics are common in woody deciduous trees, where maximum root TNC levels are generally attained before leaf fall after seed/fruit maturation (Loescher et al. 1990). During dormancy, tallow root TNC levels decline slightly, perhaps to meet maintenance respiration and metabolic demands (sensu Wilson et al. 1975, Glerum 1980, Loescher et al. 1990, Kozlowski 1992).

Chinese tallow root TNC levels increase during seed maturation until leaf fall, reaching $52 \%$ and $61 \%$, respectively (Table 1). These levels are higher than mesquite root TNC levels during its root replenishment stage (14\%) (Wilson et al. 1975). When foliar herbicides were applied to mesquite during this replenishment period, effective plant kill was observed (Wilson et al. 1975). Similarly, if foliar herbicides are applied

Table 1. Chinese tallow root total nonstructural carbohydrate (TNC) levels (\%) (mg/g) according to phenological stage of development. Tallow roots ( $n=4$ at each site) were collected monthly from trees in Matagorda and Brazoria Counties, Tex. from November 1995 through October 1996.

\begin{tabular}{|c|c|c|c|c|c|c|c|}
\hline \multirow[b]{2}{*}{ Phenological Stage } & \multirow[b]{2}{*}{ Date } & \multicolumn{2}{|c|}{ Overall TNC Levels ${ }^{1}$} & \multicolumn{2}{|c|}{ Riparian tallow TNC Levels } & \multicolumn{2}{|c|}{ Wetland tallow TNC Levels } \\
\hline & & $(\mathrm{x})$ & SE & $(\mathrm{x})$ & SE & $(\mathrm{x})$ & SE \\
\hline & & & $(\%)$ & & $(\%)$ & & $(\%)$ \\
\hline Dormancy & Nov 95-Jan 96 & 47.94B & 1.14 & 44.15 & 1.42 & 51.72 & 1.52 \\
\hline Bud Break & Feb 96 & 47.30B & 2.32 & 46.89 & 3.98 & 47.72 & 2.68 \\
\hline Leaf Development & Mar-Apr 96 & $41.11 \mathrm{C}$ & 1.24 & 41.44 & 1.96 & 40.79 & 1.63 \\
\hline Seed Formation & May-Jun 96 & $36.71 \mathrm{C}$ & 1.35 & 36.29 & 2.03 & 37.13 & 1.85 \\
\hline Seed Maturation & Jul-Aug 96 & $51.69 \mathrm{~B}$ & 2.56 & 51.82 & 3.97 & 51.56 & 3.37 \\
\hline Leaf Fall & Sept-Oct 96 & $60.72 \mathrm{~A}$ & 1.53 & 60.51 & 2.60 & 60.94 & 1.82 \\
\hline
\end{tabular}

${ }_{1}$ Means followed by the same letter are not different $(\mathrm{P}>0.05)$. Overall TNC levels are data combined for riparian and wetland basin tallow woodlands. 
to tallow during its replenishment period, when roots function as carbohydrate sinks, total plant kill should be observed. Phenological development in tallow should be relatively consistent among years (although timing may vary by locale) (Sosebee 1983), therefore, effective tallow control programs may be implemented on a region-wide basis. This is a plausible and attainable goal, where tree mortality has been observed in other woody plant species (i.e., mesquite, sand-shin oak, etc.) when foliar herbicide application was based on phenological development, coinciding with root TNC level increases (Boo and Pettit 1975, Wilson et al. 1975, Wan and Sosebee 1990).

Although mechanical treatment (i.e., shredding, mowing, etc.) of Chinese tallow has had relatively limited success due to tallow's ability to resprout after stem damage (Jubinsky 1994), these data also may be used to time such treatments. Contrary to herbicidal applications, where treatment should coincide with root TNC replenishment, mechanical control should coincide with lowest root TNC concentration. If mechanical treatment coincides with tallow's seed formation stage (i.e., period of lowest root TNC levels) a higher degree of control should be observed more than at other times of the year (Table 1).

This study provides a first step toward Chinese tallow control and management. These root TNC data can be used to time treatments (herbicidal and mechanical) on a region-wide level; from Texas to Florida into North Carolina, regardless of tallow woodland type (i.e., riparian or wetland basin woodland). Unfortunately, these data provide a post-hoc approach to tallow management. Prescribed burning, a proper rotational grazing scheme, and other such land management practices should be used to prevent tallow establishment in areas where it is presently absent or in low densities. Finally, land managers must have a plan to keep tallow out of treated areas or benefits will be short-lived.

\section{Literature Cited}

Boo, R.M. and R.D. Pettit. 1975. Carbohydrate reserves in roots of sand shin oak in west Texas. J. Range Manage. 28:469-472.
Brady, H.A. and 0. Hall. 1976. Relation of sugar changes and herbicide susceptibility in woody plants. So. Weed Sci. Soc. Proc. 29:276-283.

Bruce, K.A. 1993. Factors affecting the biological invasion of the exotic Chinese tallow tree (Sapium sebiferum) in the Gulf Coast prairie of Texas. M. S. Thesis, Univ. Houston, Houston, Tex.

Bruce, K.A., G.N. Cameron, P. A. Harcombe, and G. Jubinsky. 1997. Introduction, impact on native habitats, and management of a woody invader, the Chinese tallow tree (Sapium sebiferum L. Roxb.). Natural Areas J. 17:255-260.

Cameron, G.N. and T.W. LaPoint. 1978. Effects of tannins on the decomposition of Chinese tallow leaves by terrestrial and aquatic invertebrates. Oecologia 32:349-366.

Conner, W.H. 1994. The effect of salinity and waterlogging on the growth and survival of baldcypress and Chinese tallow seedlings. J. Coastal Res. 10:1045-1049.

Conway, W.C. 1997. Avian behavior in Chinese tallow woodlands and evaluating the potential control and allelopathic interference of Chinese tallow. M. S. Thesis, Texas Tech Univ., Lubbock, Tex.

Coyne, P.I. and C.W. Cook. 1970. Seasonal carbohydrate reserve cycles in eight desert range species. J. Range Manage. 23:438-444.

Diamond, D.D. and F.E. Smeins. 1984. Remnant grassland and vegetation affinities of the upper coastal prairie of Texas. Southwest Nat. 29:321-334.

Fick, W.H. and R.E. Sosebee. 1983. Translocation and storage of ${ }^{14} \mathrm{C}$-labeled total nonstructural carbohydrates in honey mesquite. J. Range Manage. 34:205-208.

Glerum, C. 1980. Food sinks and food reserves of trees in temperate climates. $\mathrm{N}$. Z. J.Forest Sci. 10:176-185.

Hopkins, W.G. 1995. Introduction to plant physiology. John Wiley and Sons, Inc. New York, N. Y.

Hunt, K.W. 1947. The Charleston woody flora. Amer. Midl. Nat. 37:670-756.

Isebrands, J.G. and N.D. Nelson. 1983. Distribution of $\left[{ }^{14} \mathrm{C}\right]$-labeled photosynthates, within intensively cultured Populus clones during the establishment year Physiol. Plant. 59:9-18.

Jones, R.H. 1993. Influence of soil temperature on root competition in seedlings of Acer rubrum, Liquidambar styricaflua, and Sapium sebiferum. Amer. Midl. Nat. 130:116-126.

Jones, R.H. and K.W. McLeod. 1989. Shade tolerance in seedlings of the Chinese tallow tree, American sycamore, and cherrybark oak. Bull. Torr. Bot. Club 116:371-377.

Jones, R.H. and K.W. McLeod. 1990. Growth and photosynthetic responses to a range of light environments in Chinese tal- lowtree and Carolina ash seedlings. Forest Sci. 26:851-862.

Jubinsky, G. 1994. A review of the literature. Chinese tallow (Sapium sebiferum). Fla. Dept. Env. Prot., Bur. Aqu. Plant Manage, Tech Serv. Sec. TSS-93-03.

Kozlowski, T.T. 1992. Carbohydrate sources and sinks in woody plants. Bot Rev. 58:107-222.

Loescher, W.H., T. McCamant, and J.D. Keller. 1990. Carbohydrate reserves, translocation, and storage in woody plant roots. HortSci. 25:274-281.

Menke, J.W. and M.J. Trlica. 1981. Carbohydrate reserve, phenology, and growth cycles of nine Colorado range species. J. Range Manage. 34:269-277.

Mounsif, M. 1986. Carbohydrate trends in Artemisia caudata. M. S. Thesis, Texas Tech Univ., Lubbock, Tex.

Russell, L.H., W.L. Schwartz, and J.W. Dollahite. 1969. Toxicity of Chinese tallow tree (Sapium sebiferum). Amer. J. Vet. Res. 30:1233-1238.

Scheld, H.W. and J.R. Cowles. 1981. Woody biomass potential of the Chinese tallow tree. Econ. Bot. 35:391-397.

Scheld, H. W., J.R. Cowles, C.R. Engler, R. Kleiman, and E.B. Schultz, Jr. 1984. Seeds of the Chinese tallow tree as a source of chemicals and fuels. Pp 81-101. In: E. B. Schultz, Jr. and R. P. Morgan (eds). Fuels and chemicals from oilseeds: technology and policy options. Westview Press, Amer. Assoc. for Advancement of Sci.

Smeins, F.E., D.D. Diamond, and C.W. Hanselka. 1992. Coastal prairie. Pp 269-290. In: R. T. Coupland (ed). Ecosystems of the world: natural grasslands in the western hemisphere. Elsevier Sci. Publ. Co., Inc. New York, N. Y.

Sosebee, R.E. 1983. Considerations in brush and weed control. Pp 27-43. In: K.C. McDaniel, (ed). Proc Brush Manage. Symp., Soc. Range Manage., Albuquerque, N. M. 1O4pp.

Wan, C. and R.E. Sosebee. 1990. Relationship of photosynthetic rate and edaphic factors to root carbohydrate trends in honey mesquite. J. Range Manage. 43:171-176.

Wilson, R.T., B.E. Dahl, and D.R. Krieg. 1975. Carbohydrate concentrations in honey mesquite roots in relation to phenological development and reproductive condition. J. Range Manage. 28:286-289.

Yemm, E.W. and A.J. Willis. 1954. The estimation of carbohydrates in plant extracts of anthrone. J. Range Manage. 28:286-289.

Zar, J.H. 1996. Biostatistical analysis. Prentice-Hall, Inc., Upper Saddle River, N. J. of cucumbers to low temperatures. $(\mathrm{Cz})$. Czech. Min. Zemedel. Les. Hospodar. Ustav Vedeckotech. Inform. Restlinna Vyroba 39:1113-1125. 